Jurnal Akuntansi dan Investasi, Vol. 18 No. 1, Hlm: 119-127, Januari 2017

Artikel ini tersedia di website: http://journal.umy.ac.id/index.php/ai

DOI: $10.18196 /$ jai.18164

\title{
Perbandingan Prediksi Financial Distress dengan Model Altman, Grover dan Zmijewski
}

\author{
Barbara Gunawan $^{1 *}$; Rahadien Pamungkas'; Desi Susilawati ${ }^{2}$ \\ 'Program Studi Akuntansi Universitas Muhammadiyah Yogyakarta, Bantul, Indonesia \\ ${ }^{2}$ Program Studi Akuntansi Terapan Universitas Muhammadiyah Yogyakarta, Bantul, Indonesia
}

\begin{tabular}{l}
\hline A R T I C L E I N F O \\
\hline Article history: \\
received 17 Nov 2016 \\
revised 14 Des 2016 \\
accepted 19 Des 2016
\end{tabular}

Keywords:

Keywords:

Financial Distress;

Altman Model; Grover

Model; Zmijewski Model

\begin{abstract}
A B S T R A C T
This study aims to find predictors model of financial distress which are the most accurate in predicting the condition of financial distress at manufacturing companies. The population of this research is the manufacturing companies that listed on the Indonesia Stock Exchange (known as BEI) in 2014. In this research, the technique of sampling used is purposive sampling. The sample of this research totaled 110 manufacturing company. Total data in the research is 110 annual reports. Methods of analysis is used multiple linear regressions using SPSS program 15.00.The results show that the Altman model, Grover model, and Zmijewski model can be used to predict the condition of financial distress. Among of these three models, model Zmijewski is the most accurate model to predict the condition of financial distress at manufacturing companies.
\end{abstract}

(c) 2017 JAI. All rights reserved

\section{PENDAHULUAN}

Pada awal tahun 2015 Bursa Efek Indonesia (BEI) mengumumkan saham-saham yang dikeluarkan (delisting) di BEI. Perusahaan yang sahamnya dikeluarkan dari BEI yaitu Davomas Abadi Tbk. Perusahaan tersebut dicatat sebagai emiten di BEI pada tanggal 22 desember 1994 dan dikeluarkan (delisting) BEI pada tanggal 21 januari 2015. Hal tersebut memperlihatkan bahwa perusahaan yang sudah lama beroperasi tetap beresiko mengalami kebangkrutan. Berdasarkan kondisi tersebut, analisis gejala-gejala kebangkrutan seperti financial distress (kesulitan keuangan) masih sangat penting dilakukan.

Analsis financial distress sangat penting dilakukan oleh perusahaan sebagai instropeksi perusahaan guna memperbaiki konndisi perusahaan dimasa mendatang. Selain perusahaan, analisis financial distress juga penting dilakukan oleh investor. Investor membutuhkan informasi tersebut guna memberikan keputusan mengenai investasinya.

Berbagai model analisis telah dikembangkan untuk memprediksi financial distress sebagai tanda awal kebangkrutan suatu perusahaan. Model analisis tersebut diantaranya adalah model Altman, model Grover, dan model Zmijewski.
Terdapat beberapa penelitian mengenai ketepatan prediksi financial distress yang telah dilakukan sebelumnya, di antaranya yaitu Wulandari et al. (2014), Pambekti et al. (2014), Hadi dan Anggraeni (2011), Rifqi (2009), Prihanthini dan Sari (2013), Wulandari et al. (2014). Hasil penelitian sebelumnya masih menunjukkan adanya inkonsistensi hasil. Perbedaan tersebut disebabkan karena pada dasarnya setiap model memiliki karakteristik yang berbeda. Suatu model mungkin tepat untuk jenis perusahaan tertentu namun kemungkinan tidak tepat untuk jenis perusahaan lainnya. Pada penelitian-penelitian terdahulu objek penelitian hanya terbatas pada satu sub sektor perusahaan yang terdaftar di BEI, contohnya seperti pada penelitian Wulandari et al. (2014) dan penelitian Prihanthini dan Sari (2013), yang mana objek penelitian hanya terbatas pada perusahaan food and beverage. Berbagai hal tersebut di atas memotivasi penulis untuk melalukan penelitian ini.

Untuk mendapatkan hasil penelitian yang bersifat lebih umum (general), maka dibutuhkan penelitian yang lebih luas cakupannya, yaitu dengan memperluas sampel penelitian. Selain itu, penelitian ini mencoba untuk membandingkan tiga model prediktor financial distress, yakni model Altman, Grover dan Zmijewski. Dari 
perbandingan tiga model ini diharapkan dapat ditemukan model yang memiliki kualitas prdiksi paling bagus atau akurat.

Hasil penelitian ini diharapkan dapat memberikan kontribusi dalam perkembangan konsep penilaian financial distress, khususnya dalam konteks perusahaan yang terdaftar di Bursa Efek Indonesia (BEI). Dari segi praktis, hasil penelitian ini diharapkan memberikan informasi bagi para investor dan para regulator atau pembuat kebijakan, khususnya terkait penyusunan peraturan pengawasan kondisi keuangan perusahan-perusahaan yang terdaftar di BEI, yang juga berkaitan dengan perlindungan investor.

\section{TINJAUAN LITERATUR DAN PERUMUSAN HIPOTESIS}

\section{Financial Distress}

Financial distress merupakan tahap penurunan kondisi keuangan perusahaan. Financial distress terjadi sebelum terjadinya kebangkrutan atau likuidasi (Widarjo dan Setiawan, 2009). Menurut Adnan dan Kurnasih (2000), financial distress merupakan keadaan perusahaan yang mengalami kesulitan dalam menghasilkan laba atau perusahaan tersebut mengalami defisit. Selain itu, kondisi perusahaan yang mengalami financial distress disampaikan oleh Anggarini dan Ardiyanto (2010), yang menyatakan bahwa perusahaan yang mengalami financial distress akan menghadapi beberapa kondisi. Kondisi yang pertama yaitu perusahaan mengalami kegagalan pembayaran kembali utang yang sudah jatuh tempo kepada kreditur. Kondisi yang kedua yaitu perusahaan tersebut berada dalam kondisi yang tidak solvable (insolvable).

\section{Model Altman}

Wulandari et al. (2014) menjelaskan bahwa model Altman dikembangkan menggunakan model step-wise Multivariate Discriminant Analysis (MDA). MDA merupakan teknik statistika yang yang biasa digunakan untuk membuat model yang mana variabel dependennya merupakan variabel kualitatif. Berikut ini merupakan persamaan model Altman yang digunakan untuk memprediksi financial distress.

$$
\begin{aligned}
\mathrm{Z} & =0,717 \mathrm{X} 1+0,847 \mathrm{X} 2+3,107 \mathrm{X} 3+0,420 \mathrm{X} 4+ \\
& 0,988 \mathrm{X} 5
\end{aligned}
$$

Keterangan:

$\mathrm{X} 1=$ Working capital to total asset (WCTA)

$\mathrm{X} 2=$ Retained earning to total asset (RETA)

$\mathrm{X} 3=$ Earning before interest and taxes to total asset (EBITTA)

$\mathrm{X} 4=$ Market value of equity / book value of debt (MVEBVD)

$\mathrm{X} 5=$ Sales $/$ total asset (SATA)

Setelah diketahui hasil skor berdasarkan perhitungan, selanjutnya Altman menggunakan nilai cutoff 2,675 dan 1,81 dengan kriteria sebagai berikut:

1) Perusahaan yang mempunyai skor $Z>2,675$ diklasifikasikan sebagai perusahaan sehat.

2) Perusahaan yang mempunyai skor $\mathrm{Z}<1,81$ diklasifikasikan sebagai perusahaan potensial bangkrut.

3) Perusahaan yang mempunyai skor $1,81 \leq \mathrm{Z} \leq$ 2,675 diklasifikasikan sebagai perusahaan pada grey area atau daerah kelabu.

Berdasarkan penalaran diatas, maka hipotesis pertama yang diajukan adalah

H1: Model Altman dapat digunakan untuk memprediksi kondisi financial distress.

\section{Model Grover}

Penelitian Prihanthini dan Sari (2013) dijelaskan bahwa model grover merupakan model yang diciptakan oleh Jeffrey S. Grover dengan melakukan pendesainan dan penilaian ulang terhadap model Altman Z-score.

Score $=1,650 \mathrm{X} 1+3,404 \mathrm{X} 3-0,016 \mathrm{ROA}+0,057$

Keterangan :

$\mathrm{X} 1=$ Working capital total asset (WCTA)

$\mathrm{X} 3=$ Earning before interest and taxes / total asset (EBITTA)

$\mathrm{ROA}=$ net income $/$ total assets

Model Grover mengkategorikan perusahaan dalam keadaan bangkrut apabila skor yang dihasilkan berdasarkan perhitungan persamaan kurang dari atau sama dengan $-0,02(\mathrm{Z} \leq-0,02)$. Sedangkan nilai untuk perusahaan yang dikategorikan dalam keadaan tidak bangkrut atau sehat adalah lebih dari atau sama dengan $0,01(\mathrm{Z} \geq 0,01)$. Berdasarkan penalaran diatas, maka hipotesis kedua yang diajukan adalah: 
H2: Model Grover dapat digunakan untuk memprediksi kondisi financial distress

\section{Model Zmijewski}

Dalam penelitian Fatmawati (2012) dijelaskan bahwa model Zmijewski menggunakan analisis rasio yang digunakan untuk mengukur kinerja, leverage, dan likuiditas suatu perusahaan. Berikut ini merupakan persamaan model Zmijewski:

$\mathrm{Z}=-4,3-4,5 \mathrm{X}_{1}+5,7 \mathrm{X}_{2^{-}}-0,004 \mathrm{X}_{3}$

Keterangan:

$\mathrm{X}_{1}=$ Return On Asset (ROA)

$\mathrm{X}_{2}=$ Debt Ratio (TLTA)

$\mathrm{X}_{3}=$ Current Ratio $(C A C L)$

Cutoff yang berlaku pada model zmijewski adalah 0 . Artinya, jika perusahaan memiliki skor lebih besar dari atau sama dengan 0, maka perusahaan tersebut diprediksi akan mengalami financial distress dimasa depan. Namun, jika nilai skor perusahaan kurang dari 0 maka perusahaan tersebut diprediksi tidak akan mengalami finnancial distress (Wulandari, 2014). Berdasarkan penalaran diatas, maka hipotesis ketiga dan keempat yang diajukan adalah:

H3: Model Zmijewski dapat digunakan untuk memprediksi kondisi financial distress.

H4: Model Altman memiliki tingkat akurasi tertinggi dalam memprediksi kondisi financial distress.

\section{METODE PENELITIAN}

\section{Sampel dan Data}

Sampel dalam penelitian ini adalah perusahaan manufaktur yang terdaftar di Bursa Efek Indonesia (BEI). Pemilihan sampel dalam penelitian ini menggunakan teknik pusposive sampling. Kriteria umum yang harus dipenuhi oleh seluruh sampel, yaitu: Perusahaan harus mengungkapkan laporan tahunan lengkap pada tahun 2014 dan Perusahaan menyajikan data keuangan lengkap yang berkaitan dengan variabel penelitian.

Data penelitian ini adalah data sekunder. Adapun teknik pengumpulan data dilakukan dengan metode arsip. Data yang digunakan yaitu laporan keuangan perusahaan tahun 2014.
Sumber data tersebut diperoleh dari Indonesian Capital Market Directory (ICMD) dan juga dapat diakses di laman: www.idx.co.id.

\section{Pengukuran Variabel}

Variabel dependen dalam penelitian ini adalah financial distress diukur dengan variabel dummy, $1=$ perusahaan yang mengalami financial distress; 0 = perusahaan sehat. Kriteria khusus digunakan untuk menentukan apakah perusahaan mengalami financial disterss atau tidak. Perusahaan dikatakan mengalami financial disterss apabila: (1) perusahaan tersebut memiliki ekuitas negatif yakni Total Utang perusahaan melebihi Total Asetnya (TL $>$ TA); atau (2) perusahaan memiliki net income negatif selama 2 (dua) tahun berturut-turut (Luciana, 2006).

\section{Model Altman, Grover, dan Zmijewski}

Variabel independen dalam penelitian ini yaitu model Altman, model Grover, dan model Zmijewski. Vriabel yang diteliti adalah yang diteliti adalah Working capital/total asset (WCTA), Retained Earnings/Total asset (RETA), Earnings before interest and taxes/total asset (EBITTA), Market value of equity/book value of total debt (MVEBVD), Sales/Total asset (SATA), Total liabilities/total asset (TLTA), Return On Asset (ROA), Current asset/current liabilities (CACL). Berikut adalah definisi pengukuran variabelvariabel tersebut:

Working capital/total asset $($ WCTA) $=$ (Aset Lancar - Hutang Lancar)/Total Aset, sesuai dengan yang digunakan dalam penelitian Cahyaningrum dan Haryanto (2012).

Retained Earnings/Total asset (RETA) = Laba ditahan/Total Aset, sesuai dengan penelitian Ardiyanto dan Prasetiono (2011).

Earnings before interest and taxes/total asset $($ EBITTA $)=$ Pendapatan sebelum Bunga dan Pajak/Total Aset, sesuai dengan yang digunakan dalam penelitian Maryati dan Zulkarnain (2014).

\section{Market value of equity/book value of total debt $($ MVEBVD) $=$ (harga saham $\mathrm{x}$}

$\sum$ saham beredar)/Total Hutang, sesuai dengan yang digunakan dalam penelitian Rismawati (2008). 
Sales/Total asset $($ SATA) $=$ Penjualan/Total Aset, sesuai dengan Ardiyanto dan Prasetiono (2011) .

Total liabilities/total asset (TLTA) $=$ Total Hutang/Total Aset sesuai dengan penelitian Ardiyanto dan Prasetiono (2011).

Return On Asset (ROA) = Laba setelah pajak / total aset, sesuai dengan penelitian Dewi (2013).

Current asset/current liabilities $(\mathrm{CACL})=$ current asset/current liabilities,sesuai dengan Ardiyanto dan Prasetiono (2011).

\section{Analisis Data}

Analisis data pada penelitian ini dilakukan dengan beberapa tahapan sebagaimana yang dijelaskan berikut.

\section{Menilai Model Fit dan keseluruhan model (Overall Model Fit)}

Penilaian model fit dilakukan dengan cara membandingkan antara nilai -2Log Likelihood awal dengan nilai -2Log Likelihood akhir. Apabila terjadipenurunan nilai -2LL maka model yang dihipotesiskan fit dengan data (Yuanita, 2010).

\section{Menilai Kelayakan Data dan Model regresi}

Kelayakan data diuji menggunakan Omnibus Test of Model. Data dikatakan layak apabila hasil nilai sig < alpha $(0,05)$. Kelayakan model regresi dinilai menggunakan Hosmer and Lemeshow's Goodnes of Fit Test (Noverio dan Dewayanto, 2011). Apabila nilai Hosmer and Lemeshow's Goodnes of Fit > 0,05, maka tidak ada perbedaan antara model dengan data sehingga model dikatakan fit (Ghozali, 2011).

\section{Koefisien Determinasi}

Koefisien determinasi (Nagelkerke's $R$ square) digunakan untuk mengetahui sejauh mana kemampuan model dalam menjelaskan variasi variabel dependen.

\section{Pengujian Hipotesis}

Pengujian hipotesis dalam penelitian ini menggunakan analisis regresi logistik biner (Regresi Binary Logistic). Analisis ini dipilih agar dapat melihat pengaruh masing-masing variabel independen terhadap variabel dependen yang berbentuk variabel biner (Wiyono, 2011).

Model regresi dalam penelitian ini adalah sebagai berikut:

$Z_{i}=\alpha+\beta_{1}$ Altman $+\beta_{2}$ Grover $+\beta_{3}$ Zmijewski $+e$

Keterangan:

$Z_{i}=$

Financial distress $(1=$ finacial distress dan $0=$ non financial distress)

$\alpha=\quad$ Konstanta

$\beta_{1}, \ldots, \beta_{3}=\quad$ Koefisien

Altman $=\quad$ Model Altman

Grover $=\quad$ Model Grover

Zmijewski $=\quad$ Model Zmijewski

$E=\quad$ Error

Berikut merupakan kriteria penerimaan hipotesis. Hipotesis satu dan tiga diterima apabila nilai sig Wald test < alpha $(0,05)$ dengan taraf signifikasi $5 \%(\alpha=0,05)$. Hipotesis 4 di uji dengan cara membandingkan nilai Nagelkerke $\boldsymbol{R}^{2}$. Model prediktor financial distress dengan Nagelkerke's $R^{\prime}$ tertinggi menggambarkan bahwa model tersebut memiliki tingkat akurasi tertinggi dibandingkan dengan model-model lainnya yang diteliti dalam penelitian ini. Nilai Nagelkerke's $\boldsymbol{R}^{2}$ setiap model didapat dengan cara melakukan pengujian ulang masing-masing model prediktor financial distress. pada proses ini terdapat tiga pengujian meliputi: 1) Model Altman terhadap Financial distress, 2) Model Grover terhadap Financial distress dan 3)Model Zmijewski terhadap Financial distress. Pengujian kali ini hanya berfokus pada nilai Nagelkerke's $R^{2}$ dan mengabaikan yang lainnya.

\section{HASIL DAN PEMBAHASAN}

Pada Tabel 1 disajikan informasi mengenai sampel yang di gunakan pada penelitian ini, yaitu Perusahaan manufaktur yang terdaftar di BEI pada tahun 2014 sebanyak 151 perusahaan. Perusahaan yang dapat dijadikan sampel berjumlah 110 karena terdapat 29 Perusahaan manufaktur yang tidak mengungkapkan laporan tahunan atau annual report dan financial report selama tahun 2014 dan sebanyak 29 perusahaan yang data variabel penelitian tidak tersedia lengkap dalam laporan keuangan tahunan perusahaan yang diterbitkan pada tahun 2014, sehingga jumlah sampel menjadi 110 perusahaan manufkatur yang terdaftar di BEI. 
Tabel 1. Kriteria Pemilihan Sampel

\begin{tabular}{lc}
\hline \multicolumn{1}{c}{ Kriteria } & Jumlah \\
\hline $\begin{array}{l}\text { Perusahaan manufaktur yang listing di BEI } \\
\text { pada tahun 2014 }\end{array}$ & 151 \\
\hline $\begin{array}{l}\text { Perusahaan manufaktur yang tidak } \\
\text { mengungkapkan laporan tahunan atau } \\
\text { annual report dan financial report selama } \\
\text { tahun 2014 }\end{array}$ & 12 \\
\hline $\begin{array}{l}\text { Data-data mengenai variabel penelitian } \\
\text { tidak tersedia lengkap dalam laporan } \\
\text { keuangan tahunan perusahaan yang } \\
\text { diterbitkan pada tahun 2014 }\end{array}$ & 29 \\
\hline Total Sampel & 110 \\
\hline Total Data & 110 \\
\hline
\end{tabular}

\section{Statistik Deskriptif}

Pada Tabel 2 disajikan Statistik Deskpritif dari data penelitian.

\section{Model Fit dan Keseluruhan Model}

Pada Tabel 3 dapat disimak bahwa telah terjadi penurunan nilai -2LogLikelihood dari analisis awal ke analaisis akhir. Hal tersebut mengindikasikan bahwa model yang dihipotesiskan fit dengan data.

Tabel 3. Perbandingan Nilai -2LogLikelihood

\begin{tabular}{lr}
\hline -2 Log likelihood & Nilai \\
\hline Awal (Block Number $=0)$ & 87,628 \\
Akhir (Block Number $=1)$ & 39,052 \\
\hline
\end{tabular}

\section{Kelayakan Data dan Model Regresi}

Pada Tabel 4 dapat disimak bahwa nilai signifikansi (Sig.) adalah $0,00<$ alpha 0,05 , yang diartikan data penelitian layak digunakan pada analisis financial distress.

Tabel 4. Hasil Uji Kelayakan Data

\begin{tabular}{lccc}
\hline & Chi-Square & df & Sig. \\
\hline Step & 48.575 & 3 & .000 \\
Block & 48.575 & 3 & .000 \\
Model & 48.575 & 3 & .000 \\
\hline
\end{tabular}

Selanjutnya, hasil pengujian kelayakan model regresi mengenai kelayakan model menggunakan SPSS dipeorleh nilai signifikansi (Sig.) sebesar $0,993>$ alpha 0,05. Dengan demikian dapat disimpulkan bahwa model regresi layak digunakan untuk melanjutkan pengujian dalam penelitian ini.

\section{Uji Koefisien Determinasi.}

Hasil uji koefesien determinasi menemukan kan nilai Nagelkerke $R$ Square sebesar 0,650, yang artinya variabel independen (model Altman, Model Grover dan Model Zmijewski) mampu menjelaskan variabel dependen (financial distress) sebesar $65 \%$ dan sisanya di jelaskan variabel lain yang tidak diteliti.

\section{Hasil Pengujian hipotesis 1,2 dan 3 (Uji Wald)}

Untuk pembahasan hipotesis 1, 2, dan 3 disajikan pada Tabel 5. Hasil pengujian menunjukkan bahwa persamaan regresi logistik adalah sebagai berikut:

\section{$\mathrm{Z}_{\mathrm{i}}=-0,999-0,448 \mathrm{Altman}-1,839$ Grover + $0,534 Z$ mijewski $+\mathrm{e}$}

Hasil tersebut memperlihatkan bahwa nilai sig untuk model Altman sebesar 0,043 < alpha 0,05 , dengan nilai koefisien regresi sebesar $-0,488$, sehingga hipotesis H1 diterima, yang artinya model Altman dapat digunakan untuk memprediksi kondisi financial distress. Dari Tabel 5 juga dapat disimak bahwa nilai sig. untuk model Grover sebesar $0,023<$ alpha 0,05 , dengan nilai koefisien regresi sebesar -1,839 sehingga hipotesis H2 diterima. Dari hasil maka tersebut dapat disimpulkan bahwa model Grover dapat digunakan untuk memprediksi kondisi financial distress. Untuk pengujian model Zmijewski ditemukan bahwa nilai sig. sebesar $0,001<$ alpha 0,05 , dengan nilai koefisien regresi sebesar 0,354 yang berarti H3 diterima. Dari hasil tersebut dapat disimpulkan model Zmijewski dapat digunakan untuk memprediksi kondisi financial distress.

Tabel 2. Hasil Statistik Deskriptif

\begin{tabular}{lccccc}
\hline & N & Minimum & Maximum & Mean & Std. Deviasi \\
\hline Financial distress & 110 & 0 & 1 &, 14 &, 345 \\
Model Altman & 110 & $-6,7061$ & 16,9153 & 3,108648 & 3,6661916 \\
Model Grover & 110 & $-5,1268$ & 6,4167 &, 509181 & 1,1828695 \\
Model Zmijewski & 110 & $-21,5187$ & 17,2824 & $-1,346023$ & 3,5275980 \\
\hline
\end{tabular}


Tabel 5. Pengujian hipotesis 1, 2 dan 3

\begin{tabular}{clcccccc}
\hline & Model & B & S.E & Wald & Df & Sig. & Exp (B) \\
\hline Step & Altman &,- 448 &, 221 & 4,105 & 1 &, 043 &, 639 \\
$1^{\mathrm{a}}$ & Grover & $-1,839$ &, 810 & 5,157 & 1 &, 023 &, 159 \\
& Zmijewski &, 534 &, 162 & 10.843 & 1 &, 001 & 1,706 \\
& Constant &,- 999 &, 503 & 3,949 & 1 &, 047 &, 368 \\
\hline
\end{tabular}

a. variable (s) entered on step 1: Altman, Grover, Zmijewski

Hasil pengujian hipotesis menunjukkan bahwa model Altman mampu memprediksi kondisi financial distress. Hal ini menunjukkan bahwa rasio-rasio keuangan yang digunakan pada model Altman mampu menggambarkan kondisi financial distress suatu perusahaan. Model Atman mampu memprediksi kondisi financial distress karena kelima rasio keuangan yang digunakan mampu menjelaskan kondisi financial distress. Rasio keuangan yang digunakan adalah WCTA, RETA, EBITTA MVEBVD, dan SATA. Kelima rasio keuangan tersebut menggambarkan kondisi keuangan perusahaan, dimana kondisi keuangan sangat erat kaitanya dengan kondisi financial distress.

Menurut Hapsari (2007) Working Capital to Total Asset merupakan rasio yang mengukur likuiditas suatu perusahaan. likuiditas tentu tentu berkaitan erat dengan kondisi financial distress. Semakin tinggi modal kerja (Working Capita) maka kondisi keuangan perusahaan semakin baik dan kemungkinan mengalami kondisi financial distress akan semakin kecil. Retained Earning to Total Assets memperlihatkan kemampuan perusahaan dalam memperoleh keuntungan (Kartika, 2012). Rasio earning before interest and taxes to total asset mengukur produktivitas aktiva perusahaan dalam menghasilkan laba sebelum bunga dan pajak. Market Value Equity to Book Value of Total Debt (rasio modal sendiri terhadap total utang). Rasio ini merupakan rasio yang digunakan untuk mengukur kemampuan perusahaan dalam memberikan jaminan kepada setiap hutangnya melalui modal sendiri (Kartika, 2012).

Hasil penelitian ini sesuai dengan Penelitian Pambekti et al. (2014) yang membuktikan bahwa model Altman dapat digunakan untuk memprediksi financial distress. selain itu penelitian penelitian Wulandari et al. (2014) juga membuktikan bahwa model Altman dapat digunakan untuk memprediksi kesulitan keuangan perusahaan.

Hasil pengujian hipotesis juga menunjukkan bahwa model Grover mampu memprediksi kondisi financial distress. Hal ini menunjunjukkan bahwa rasio-rasio keuangan yang digunakan pada model Grover mampu menggambarkan kondisi financial distress suatu perusahaan. Model grover menggunakan tiga rasio keuangan untuk memprediksi financial distress.

Rasio pertama yaitu rasio working capital to total assets. Rasio ini akan memperlihatkan likuiditas perusahaan. Semakin tinggi rasio ini maka perusahaan akan terhindar dari financial distress. Rasio selanjutnya yaitu EBIT to Total assets. Rasio ini akan memperlihatkan tingkat produktivitas aktiva dalam menghasilkan laba sebelum pajak dan bunga. Semakin tinggi rasio ini maka perusahaan akan semakin terhindar dari financial distress. Rasio yang terakhir yaitu ROA. Menurut Herdiningtyas et al. (2006) ROA merupakan rasio yang digunakan untuk mengukur kemampuan manajemen dalam memperoleh laba yang dihasilkan dari rata-rata aset. Semakin besar ROA, maka semakin kecil kemungkinan perusahaan dalam kondisi bermasalah.

Hasil ini konsisten dengan dengan penelitian Pambekti (2014) membuktikan bahwa model Grover dapat digunakan untuk memprediksi financial distress. Penelitian Prihanthini dan Sari (2013) membuktikan bahwa model Grover merupakan model prediksi yang paling sesuai diterapkan pada perusahaan Food and Beverage yang terdaftar di Bursa Efek Indonesia (BEI).

Hasil pengujian menunjukkan bahwa model Zmijewski mampu memprediksi kondisi financial distress. Hal ini menunjunjukkan bahwa rasiorasio keuangan yang digunakan pada model Zmijewski mampu menggambarkan kondisi financial distress suatu perusahaan. Model Zmijewski menggunakan tiga rasio keuangan. Rasio yang pertama yaitu ROA. ROA yaitu perbandingan antara laba setelah pajak dengan jumlah aset (Cahyaningrum dan Haryanto, 2012). Rasio ini akan menunjukkan tingkat kemampuan perusahaan dalam menghasilkan laba dari ratarata asetnya. Semakin tinggi ROA maka kondisi kesehatan perusahaan semakin baik, dan kemungkinan mengalami kondisi financial distress akan semakin kecil.

Rasio kedua yaitu debt ratio. Rasio ini akan mengukur tingkat persentase aktiva yang di biayai 
oleh hutang. Rasio yang terakhir yaitu current ratio. Rasio ini digunakan untuk mengukur likuiditas perusahaan. likuiditas merupakan kempuan perusahaan dalam memenuhi kewajiban jangka pendeknya. Semakin tinggi kemampuan perusahaan dalam memenuhi kewajibanya, maka perusahaan tersebut dikatakan sebagai perusahaan yang sehat.

Hasil penelitian ini sesuai dengan penelitian Pambekti et al. (2014), Wulandari et al. (2014), Prihanthini et al. (2013), dan Fatmawati (2012) membuktikan bahwa model Zmijewski dapat digunakan untuk memprediksi financial distress. Hasil penelitian Vatmawati (2012) memperlihatkan bahwa model Zmijewski merupakan prediktor delisting terakurat. Penelitian Pambekti (2014) menyimpulkan bahwa model Zmijewski adalah model prediksi financial distress yang paling tepat digunakan untuk memprediksi financial distress perusahaan di masa yang akan datang.

\section{Hasil Pengujian Hipotesis 4}

Hasil Uji Koefisien Determinasi Model Altman menunjukkan nilai -2 Log likelihood sebesar 62,339 dengan Nagelkerke R Square 0,374. Hasil Model Grover menunjukkan nilai -2 Log likelihood sebesar 57,018 dengan Nagelkerke R Square 0,442. Hasil Uji Koefisien Determinasi Model Zmijewski menunjukkan nilai -2 Log likelihood sebesar 55,580 dengan Nagelkerke R Square 0,460.

\section{Tabel 6. Hasil Uji Tingkat Akurasi}

\begin{tabular}{clc}
\hline & Model prediktor & Nagelkerke $\boldsymbol{R}^{\boldsymbol{C}}$ \\
\hline 1 & Model Zmijewski & 0,460 \\
2 & Model Grover & 0,442 \\
3 & Model Altman & 0,374 \\
\hline
\end{tabular}

Dari Tabel 6 dapat disimak urutan tingkat Akurasi prediksi financial distress yang dimulai dari yang paling tinggi hingga yang paling rendah. Model dengan tingkat akurasi tertinggi yaitu Model Zmijewski $(0,460)$ kemudian model Grover $(0,442)$ dan yang paling rendah adalah model Altman (0,374). Pengujian menunjukkan bahwa model yang memiliki tingkat akurasi paling tinggi dalam memprediksi financial distress adalah Model Zmijewski. Hasil ini tidak sesuai dengan hipotesis yang diajukan. Hal tersebut memperlihatkan bahwa H4 ditolak, yang artinya model Altman bukan merupakan prediktor financial distress yang memiliki tingkat akurasi tertinggi diantara tiga variabel independen yang diteliti. Model yang paling akurat dalam memprediksi financial distress pada perusahaan manufaktur adalah model Zmijewski.

Pengujian menunjukkan bahwa model yang memiliki tingkat akurasi paling tinggi dalam memprediksi financial distress adalah Model Zmijewski. Hasil penelitian Fatmawati (2012) memperlihatkan bahwa model Zmijewski merupakan prediktor delisting terakurat. Penelitian Pambekti et al. (2014) menyimpulkan bahwa model Zmijewski adalah model prediksi financial distress yang paling tepat digunakan untuk memprediksi financial distress perusahaan di masa yang akan datang.

\section{SIMPULAN}

Penelitian ini bertujuan untuk menguji tingkat ketepatan model Altman, model Grover dan model Zmijewski dalam memprediksi kondisi financial distress pada perusahaan manufaktur. Hasil perbandingan ketiga model prediksi funancial distress menunjukkan bahwa tingkat akurasi prediksi financial distress tertinggi hingga terendah berturut-turut yaitu model Zmijewski, model Grover dan Model Altman.

Model Zmijewski memiliki tingkat akurasi tertinggi dalam memprediksi kondisi financial distress didasarkan pada hasil uji koefisien detertminasi. Model Zmijewski memiliki nilai nagelkerke $R$ square paling tinggi diantara tiga model yang diuji. Jika dibandingkan dengan dua model lainya, persamaan model Zmijewski memiliki karakteristik yang berbeda. Model Zmijewski lebih menekankan pada ukuran utang, sedangkan dua model lainya lebih menekankan pada ukuran profitabilitas.

Penelitian ini memiliki beberapa keterbatasan yaitu model prediksi financial distress sudah banyak dikembangkan, namun penelitian ini hanya membandingkan tiga model prediktor fianancial distress saja. Penelitian selanjutnya sebaiknya membandingkan lebih banyak model prediksi financial distress, seperti Ohlson, Springate, Fulmer, Ca-Score dll, Sehingga hasil penelitian benar-benar mampu menjawab prediktor financial distress mana yang terbaik. Keterbatasan selanjutnya adalah terkait sampel. Sampel penelitian yang digunakan dalam penelitian ini hanya terbatas pada perusahaan manufaktur saja. Penelitian selanjutnya sebaiknya 
memperluas sampel penelitian untuk mendapatkan hasil penelitian yang bersifat general.

\section{DAFTAR PUSTAKA}

Adnan, M. A. dan E. Kurniasih. 2000. Analisis Tingkat Kesehatan Perusahaan Untuk Memprediksi Potensi Kebangkrutan Dengan Pendekatan Altman (The Analysis of Corporates' Health to Predict Their Bankruptcy Potentials Using The Altman Model). Jurnal Akuntansi dan Auditing Indonesia, 7 (2).

Anggarini, T. V. dan M. D. Ardiyanto. 2010. Pengaruh Karakteristik Komite Audit Terhadap Financial Distress. Disertasi Doktoral, Universitas Dipponegoro.

Ardiyanto, F. D. dan P. Prasetiono. 2011, "Prediksi Rasio Keuangan Terhadap Kondisi Financial distress Perusahaan Manufaktur Yang Terdaftar di Bursa Efek Indonesia. Jurnal Dinamika Ekonomi \& Bisnis, 8 (1), 1-14.

Cahyaningrum, N. H. dan A. M. Haryanto. 2012. Analisis Manfaat Rasio Keuangan dalam Memprediksi Pertumbuhan Laba (Studi Kasus: Perusahaan Manufaktur yang terdaftar di Bursa Efek Indonesia periode 2005 sampai dengan 2010). Disertasi Doktoral, Universitas Diponegoro.

Dewi, S. S. 2013. Pengaruh Karakteristik Perusahaan Terhadap Corporate Social Responsibilitydisclosure pada Perusahaan Manufaktur yang Terdaftar di BEI. Jurnal Ilmu \& Riset Akuntansi, 2 (3), 9-11.

Fatmawati, M. 2012. Penggunaan The Zmijewski Model, The Altman Model, dan The Springate Model Sebagai Prediktor Delisting. Jurnal Keuangan dan Perbankan, 16 (1), 56-65.

Ghozali, I. 2011. Aplikasi Multivariate dengan Program IBM SPSS 19. Semarang: Badan Penerbit Universitas Diponegoro.

Hadi, S. dan A. Anggraeni. 2011. Pemilihan Prediktor Delisting Terbaik (Perbandingan Antara The Zmijewski Model, The Altman Model, dan The Springate Model). Jurnal Akuntansi \& Auditing Indonesia, 12 (2), 19.

Hapsari, E. A. 2007. Analisis Rasio Keuangan untuk Memprediksi Pertumbuhan Laba (Studi Kasus: Perusahaan Manufaktur yang terdaftar di Bursa Efek Jakarta periode
2001 sampai dengan 2005). Disertasi Doktoral, Universitas Diponegoro.

Kartika, A. 2012. Pengaruh Kondisi Keuangan dan Non Keuangan Terhadap Penerimaan Opini Going Concern Pada Perusahaan Manufaktur di BEI". Dinamika Akuntansi Keuangan dan Perbankan, 1( 1), 1-11.

Luciana, 2006, Prediksi Kondisi Financial distress Perusahaan Go Public Dengan Menggunakan Analisis Multinomial Logit. Jurnal Ekonomi dan Bisnis, 7 (2), 183-210.

Maryati, H. dan I. Zulkarnain. 2014. Analis Prediksi Financial distress Dengan Menggunakan Model Z-Score (Altman) (Studi Kasus Pt. Indocement Tunggal Prakarsa, Tbk Yang Terdaftar Di Bursa Efek Indonesia Periode 20072012). Disertasi Doktoral, Universitas Bengkulu.

Noverio, R. dan T. Dewayanto. 2011. Analisis Pengaruh Kualitas Auditor, Likuiditas, Profitabilitas dan Solvabilitas Terhadap Opini Audit Going Concern pada Perusahaan Manufaktur yang Terdaftar di Bursa Efek Indonesia. Disertasi Doktoral, Universitas Diponegoro.

Pambekti, G. T. 2014. Analisis Ketepatan Model Altman, Springate, Zmijewski, Dan Grover Untuk Prediksi Financial distress (Studi Pada Perusahaan Yang Masuk Dalam Daftar Efek Syariah Tahun 2009-2012). Disertasi Doktoral, Universitas Islam Negeri Sunan Kalijaga.

Prihanthini, N. M. dan M. M. Sari. 2013. "Prediksi Kebangkrutan Dengan Model Grover, Altman Z-Score, Springate Dan Zmijewski Pada Perusahaan Food And Beverage Di Bursa Efek Indonesia. EJurnal Akuntansi Universitas Udayana, 5 (2), 417-435.

Rifqi, M. 2009. Analisis Perbandingan Model Prediksi Financial distress Altman, Ohlson, Zmijewski, dan Springate dalam Penerapannya di Indonesia. Skripsi. Universitas Indonesia.

Saham Delisting di Bursa Efek Indonesia, http://www.sahamok.com/emiten/sahamdelisting/, diakses pada 10 juni 2015.

Widarjo, W. dan D. Setiawan. 2009. Pengaruh Rasio Keuangan Terhadap Kondisi Financial distress Perusahaan Otomotif. Jurnal Bisnis Dan Akuntansi, 11 (2), $107-$ 119. 
Wulandari, V. 2014. Analisis Perbandingan Model Altman, Springate, Ohlson, Fulmer, CA-Score dan Zmijewski Dalam Memprediksi Financial distress (studi empiris pada Perusahaan Food and Beverages yang Terdaftar di Bursa Efek Indonesia Periode 2010-2012). Jurnal Online Mahasiswa (JOM) Bidang Ilmu Ekonomi, 1 (2), 1-18.

Yuanita, I. 2010. Prediksi Finacial Distress Dalam Industri Textile Dam Garment (Bukti Empiris Di Bursa Efek Indonesia).Jurnal Akuntansi \& Manajemen, 6 (2), 101-120. 